\title{
Control of gastrointestinal parasitism with nematodes in dairy goats by treating the host category at risk
}

\author{
Hervé Hoste $^{a *}$, Christophe Chartier ${ }^{b}$, Yves Le FrileuX ${ }^{c}$
}

\begin{abstract}
aPhysiopathologie des Maladies Infectieuses et Parasitaires des Ruminants, Unité Mixte de Recherche 959 INRA/DGER, ENV Toulouse, 23 Chemin des Capelles, 31076 Toulouse, France

${ }^{b}$ Laboratoire de Recherches Caprines, AFSSA, 60 rue de Pied-de-Fond, 79012 Niort, France

${ }^{\mathrm{c}}$ Ferme Expérimentale Caprine, Station du Pradel, 07170 Mirabel, France
\end{abstract}

(Received 18 October 2001; accepted 19 March 2002)

\begin{abstract}
Infections of the gastrointestinal tract with parasitic nematodes remain one of the main limiting factors in grazing dairy goats. The usual mode of control of these parasitic diseases has up to now been based on the repeated use of anthelmintics. However, the prevalence rates of anthelmintic resistances, in particular to benzimidazoles, are now particularly high in the French dairy goat production. This situation makes it mandatory to reconsider the usual mode of control of these nematodes and to look for short term, alternative solutions which combine the control of gastrointestinal infections and management of anthelmintic resistances. One of the possible options is to leave a part of the flock without treatment during the grazing season in order to maintain alleles of susceptibility to anthelmintics within the worm populations. Previous epidemiological observations identifying the categories of host populations at risk are presented which provide the rationale for targeted applications of treatments. The results of assays on experimental flocks and from farm surveys examining the advantages and drawbacks of selective treatments are presented. The value of these results in combination with other alternative solutions of control are discussed in order to use minimum treatments with maximum benefits.
\end{abstract}

dairy goat / anthelmintic / selective treatment / anthelmintic resistance / parasitic nematode

Résumé - Maîtrise des strongyloses gastro intestinales chez les chèvres laitières par l'application de traitements ciblés. Les infestations par les nématodes du tractus gastro intestinal demeurent un des principaux facteurs limitant à l'élevage des chèvres laitières au pâturage. Le mode usuel de maîtrise de ce parasitisme reposait jusqu'à présent sur un usage répété de molécules anthelminthiques. Cependant, la prévalence des lignées résistantes aux anthelminthiques, en particulier aux benzimidazoles, en élevage caprin laitier en France, est désormais très élevée. Ce constat oblige à rechercher rapidement des

*Correspondence and reprints

Tel.: (33) 05611938 75; fax: (33) 05611939 44; e-mail: h.hoste@envt.fr 
solutions alternatives qui permettent de gérer de manière combinée le parasitisme et le développement des lignées résistantes. Un objectif commun à ces solutions est de maintenir au sein des populations de vers des allèles de sensibilité pour diluer ceux à l'origine de la résistance. Concrètement, un des moyens pour atteindre ce but se fonde sur l'application non plus systématique, mais ciblée, des traitements dans les troupeaux, en visant les animaux les plus parasités. Des données épidémiologiques, identifiant les catégories de chèvres à risque (primipares et fortes productrices de lait) au sein des troupeaux sont d'abord présentées. Les résultats d'études conduites en troupeau expérimental ou en élevages afin de valider l'application de traitements ciblés sont ensuite discutés en terme d'efficacité, d'applicabilité et de préservation des molécules antiparasitaires actuellement disponibles.

chèvre laitière / anthelminthique / résistance aux anthelminthiques / nématode parasite / traitement sélectif

\section{Table of contents}

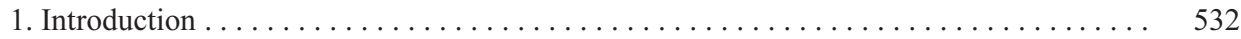

2. The situation of anthelmintic resistances in French dairy goat farms $\ldots \ldots \ldots \ldots \ldots \ldots$

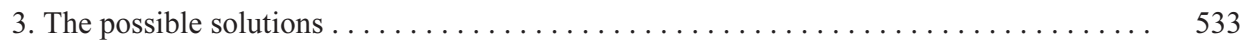

4. The general objective and principle of targeted treatment: to dilute the alleles of resistance in

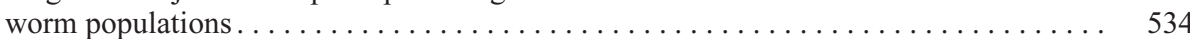

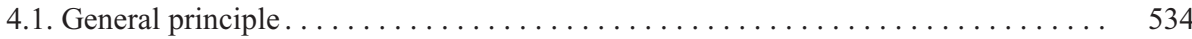

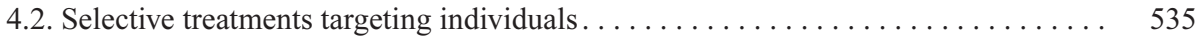

5. Basic information for selective treatments targeting specific subgroups in dairy goats . . 535

5.1. Aggregative distribution of worm populations $\ldots \ldots \ldots \ldots \ldots \ldots \ldots \ldots \ldots \ldots \ldots$

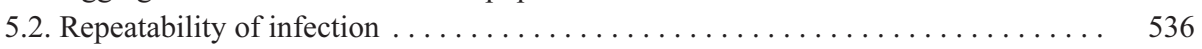

5.3. Identification of less resistant animals in relation with age $\ldots \ldots \ldots \ldots \ldots \ldots 537$

5.4. Identification of less resistant/resilient animals related to the level of production . . . 538

6. Experimental assessment of selective treatment in dairy goats . . . . . . . . . . 540

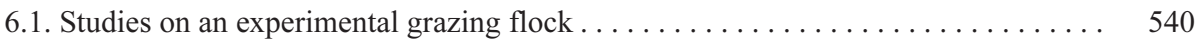

6.2. Surveys of dairy goat farms in different areas of production . . . . . . . . . . 541

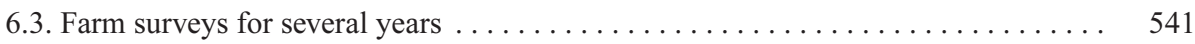

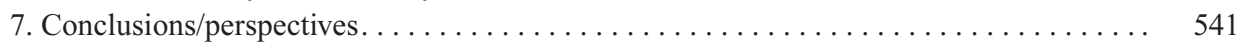

\section{INTRODUCTION}

The control of gastrointestinal trichostrongylosis in small ruminants is severely impaired by the increasing development of anthelmintic resistances $[59,60]$. Resistances to the three main families of broad spectrum anthelmintics available for the control of trichostrongyles have been described worldwide in most nematode species (see reviews by $[40,59,62])$. In addition, isolates resistant to several or even all major anthelmintic classes have now been described [70].

\section{THE SITUATION OF ANTHELMINTIC RESISTANCES IN FRENCH DAIRY GOAT FARMS}

Anthelmintic resistance is a major issue in both species of small ruminants but comparisons between sheep and goats clearly indicate that the rate of emergence and the prevalence of anthelmintic resistances are higher in goats than in sheep, and particularly in dairy goats [6, 40, 41]. Several breeding management factors are involved 
in the building of anthelmintic resistance in worm populations [62], but the higher prevalence in dairy goats has mainly been related to (i) the high frequency of treatments in goats due to their poor ability to develop a strong immune response to nematode infections [27]; (ii) the restricted choice of the anthelmintic family during lactation to avoid drug residues in milk and (iii) the specificities in the metabolism of antiparasitic drugs which make ovine doses unadapted in goats and lead to underdosing when using the ovine recommended dose [10]. These factors, that is frequent treatments, lack of alternation between molecules and underdosing, are known to favour the development of anthelmintic resistance [40]. In addition, a recent survey by questionnaires on the use of anthelmintics in goats showed that the same errors in the use of drugs are still committed despite constant efforts dedicated to informing goat farmers [29]. As a consequence, the results from surveys on anthelmintic resistance conducted during the last 15 years on dairy goat farms in France have underlined the constant increase in the prevalence rate and the seriousness of the current situation, especially for benzimidazole resistance. This situation is not unique to France since it is common to all areas with intensive breeding of goats. Benzimidazole resistance in goat nematodes was first described in 1985 , in France [42]. Since that time, several records of benzimidazole resistance have been found, particularly on farms showing a history of anthelmintic ineffectiveness. Two more recent surveys in western and southwestern parts of France give a better estimation of the prevalence of benzimidazole resistant nematodes since they were performed on a random sample of goat farms [12]. These two geographical areas present quite different management systems: a more intensive one in the western area (limited use of pastures, high frequency of anthelmintic treatments per year: 6.5) and the southwestern area being more extensive (large areas for grazing and browsing, fewer anthelmintic treatments per year: 2.5). In both surveys, prevalence of benzimidazole resistance was very high, ranging from 83 to $100 \%$, and involved the three most prevalent nematode species of goats, i.e. Trichostrongylus colubriformis, Teladorsagia circumcincta and Haemonchus contortus. In the southwestern area, benzimidazole resistance was monospecific (involving only one nematode species) on 9 farms out of 15 and multispecific on the 6 remaining farms. In addition to the previously mentioned misuse of anthelmintics, some breeding management factors are associated with the occurrence of benzimidazole resistance [61, 62]. Concerning levamisole and avermectin resistance, data remain scarce and must be interpreted with caution because of the discrepancies between field surveys based on faecal egg count reduction tests and laboratory results using in vitro or controlled tests [24, 38, 47]. Until now, levamisole resistance has been suspected in a few cases [12] whereas no information is available for the avermectin group.

\section{THE POSSIBLE SOLUTIONS}

The need for alternative or complementary solutions to anthelmintics thus appears particularly urgent in goat production. In sheep and cattle, several options are currently explored which are aimed at either improving the host response (genetic selection of resistant lines to gastrointestinal trichostrongyles, interactions between protein nutrition and parasitism, vaccines) or avoiding contamination (grazing management, use of nematophagous fungi, ...) [73, 75]. However, these solutions have received much less attention in goats than in sheep $[39,48]$, despite major differences between the two host species with regards to feeding behaviour, mucosal immunity and physiology. In addition, these options also represent long term alternatives whereas the situation of anthelmintic resistance in dairy 
goat production is such that it requires short term innovative measures.

Among these, the interaction of nematode infection and the level of protein intake has recently begun to be investigated in dairy goats in both experimental and natural conditions [17]. The principal results have been obtained for animals in the periparturient period as well as in lactation. A reduction in the periparturient rise was observed after supplying additional energy and protein to the diet during the period around kidding [18]. Similarly, in lactating goats, which were experimentally infected with trichostrongyles, the nematode egg output was decreased in the animals receiving a high protein (HP) diet compared to those with a normal protein diet. Moreover, the HP diet allowed to sustain milk production especially in the high producing animals [19]. These results have been confirmed in natural conditions since goats receiving an HP diet exhibited lower faecal egg counts and higher milk production as compared to a normal protein diet [13]. Overall, these results suggest the possibility to manipulate the protein level of the diet, in goats as in sheep $[14,35,67]$ to improve the resistance (the host responsiveness to regulate worm populations) and/or the resilience (the ability of an animal to maintain production under parasitic challenge) to nematode infection. However, the range of manipulation for protein content in farm conditions is narrow for various reasons (the high level already offered, sanitary risks of metabolic diseases, costs, restricted choice of possible protein supplementation). Clearly, further studies and data are necessary before implementation in the field. Consequently, other, more straightforward options appear useful, like those aiming at a better use of anthelmintics.

Due to the limited size of the commercial market which is represented by the production, it is unlikely that goats would easily and directly benefit from the new compounds developed and registered by the pharmaceutical industry. Hence, besides the long term alternatives previously evoked, an improved integrated use of the available anthelmintics represents one immediate and probably simpler option to preserve the efficiency of current drugs. Several programmes to reduce the pressure of selection for anthelmintic resistant worms were previously explored in sheep in Australia and in New Zealand. They were usually based on practices which tend to reduce the role of factors known to favour the emergence/development of resistance in worm populations, that is reducing the frequency of treatments; avoiding underdosing; alternating anthelmintic families and recommending, when possible, the use of narrow spectrum drugs $[15,16,76]$. On the other hand, one of the main solutions to preserve the current drugs is to stop using them without discrimination and to promote a more selective use, by targeting the most infected animals within a flock.

\section{THE GENERAL OBJECTIVE AND PRINCIPLE OF TARGETED TREATMENT: TO DILUTE THE ALLELES OF RESISTANCE IN WORM POPULATIONS}

\subsection{General principle}

Basically, most of the strategies which have been proposed to manage anthelmintic resistances aim at keeping a sufficient proportion of alleles of susceptibility in the worm populations in order to dilute the resistance genes. This objective is usually achieved by respecting a balance between the parasite populations on the pastures (larval stages), which are not in contact with the anthelmintics, and the worm populations in the hosts, which are directly submitted to the pressure of selection. This principle leads to recommendations such as (i) avoiding treatments at a periodicity/frequency corresponding to the prepatent 
periods of the worm in order to permit dissemination of susceptible eggs and alleles before any selection pressure is exerted or (ii) drenching at times when populations of parasite larvae on the pastures are relatively high compared to the worm populations in the hosts $[38,40]$.

Another possible way to keep the alleles of susceptibility within the worm populations is to act exclusively on the infrapopulation levels (parasites in the hosts) by withholding treatments from a part of the flock [1]. This measure represents the rationale for selective anthelmintic drenching by targeting the most susceptible individuals within flocks. The cornerstone for any application of selective treatments in the field is represented by the need to identify, quickly and with confidence, the most infected animals, representing the highest epidemiological risk. This could be achieved either after evaluating the intensity of infection on an individual basis, using different diagnostic methods; or by treating categories of animals within a flock, that have been identified from previous epidemiological studies, as being particularly at risk and representing a specific epidemiological threat.

\subsection{Selective treatments targeting individuals}

Two examples of selective treatments targeting individuals have been previously explored. In horses, programs for selective treatment have been developed to limit the use of anthelmintics against strongyles and preserve drug efficiency. The selection of horses to be treated was based on regular individual coproscopical examination. Horses with egg counts exceeding a predefined threshold were classified at risk and were drenched, whereas the rest of the herd remained untreated [23, 45]. The efficiency of the method to control parasitism by nematodes has been demonstrated.
In small ruminants, a similar individual approach has been adopted in South Africa to improve the control of specific infection with the haematophagous worm, Haemonchus contortus, without widespread use of antiparasitic drugs. The so-called FAMACHA ${ }^{\circledR}$ method proposed is also based on the principle of individual treatment, decided after clinical diagnosis of anaemia, using a semi quantitative evaluation of the eye mucosal colour $[68,69,71]$.

However, these methods of selective treatments applied to individuals present several drawbacks when considering their possible application to the situation in French dairy goat farms. Identification of animals based on coproscopical examination is probably easier to apply in horses or cattle than in small ruminants because of the number of samples required and the related cost. As underlined by Eysker and Ploeger [21], the cost of a diagnostic test should be low enough for farmers and veterinarians to accept it as a tool. In contrast, the FAMACHA ${ }^{\circledR}$ method is of low cost even for large flocks. However, whereas the method is well suited to control nematodes responsible for anaemia, such as $H$. contortus, it appears less adapted for infection with other genera, such as Teladorsagia or Trichostrongylus, which are not blood suckers. These two latter genera are, however, very common in temperate regions. For example, Teladorsagia circumcincta and Trichostrongylus colubriformis represent the two most prevalent species found on dairy goat farms in most geographical areas in France [7, 8, 11, 22, 31].

\section{BASIC INFORMATION FOR SELECTIVE TREATMENTS TARGETING SPECIFIC SUBGROUPS IN DAIRY GOATS}

Because of the potential difficulties for the application and acceptance by farmers of treatments targeting identified individuals 
on dairy goat farms, options for selective treatments targeting host categories at risk are considered a better solution to explore. This design is favoured by several characteristics of worm infection in dairy goat flocks.

\subsection{Aggregative distribution of worm populations}

The importance to assess the type of distribution of trichostrongyle populations among domestic ruminants has been largely underlined in the different programs for genetic selection of animals resistant to nematode infection. However, the assessment of the overdispersion of parasites in host populations is also a major criteria for the design of any selective chemotherapy [63] since it means that major gains in the reduction of pasture contamination and prevention of parasitic diseases could be obtained by treating a limited number of animals.

The aggregative distribution of nematode infections within host populations has been largely documented in sheep [52, 63-65]. This overdispersion is usually thought to mainly reflect individual variability in the acquisition and expression of the immune response against helminths. However, because it is generally considered that adult goats are less able to resist to nematode infection of the digestive tract than sheep, it appeared necessary to collect direct information on the distribution of egg excretion and nematode populations in goats. Compared to sheep, only a few studies have examined this point but the data currently available on fibre [74], meat [43] or milk producing goats $[28,30,32]$ tend to confirm that egg counts and worm populations are also aggregated in goats (Fig. 1).

\subsection{Repeatability of infection}

The evaluation of the repeatability of infection within flocks is another important point to determine before designing selective treatments targeting host categories. Assessment of significant, high coefficients of repeatability for egg output within year and between years suggests that, overall, the same animals within flocks are responsible for most nematode egg excretion and pasture contamination during a grazing season or from a grazing season to another.

In dairy goats, a study conducted for two successive years on the same experimental flock demonstrated significant coefficients

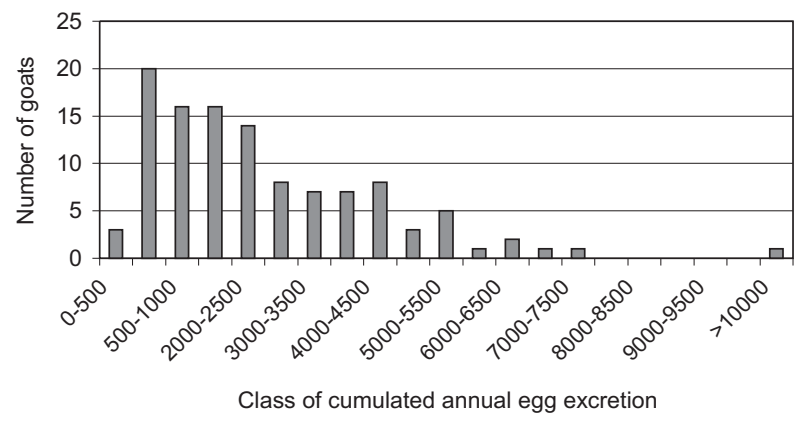

Figure 1. Frequency distribution of cumulative nematode egg excretion in a flock of naturally infected dairy goats. The flock grazed from March to October without any application of anthelmintic treatment and egg excretion was monitored every month. Ten per cent of the goats were responsible for 25 per cent of the egg excretion. 
of repeatability, within the same grazing season, not only for parasitological parameters, that is egg output, but also for pathophysiological measurements [30]. These values of repeatability coefficients measured for egg counts in dairy goats (0.25 and 0.30$)$ are close to those mentioned in Cashmere male (0.31) or female (0.19) goats [53, 54] and Angora goats [74]. In addition, repeatabilities calculated between years were also relatively high. These results in dairy goats were later confirmed from a larger survey examining the repeatability coefficients for egg excretion in farm flocks from different regions of production [32]. In most of the farms, the values for the repeatability coefficients within a year were high, ranging between 0.40 and 0.84 . All-together, these data support the hypothesis that the same animals are regularly involved in the main part of pasture contamination.

These characteristics of distribution and repeatability of egg output within flocks appear favourable for the design of a selective treatment. However, the key question remains: is it possible to identify subgroups of animals which have a high receptivity/susceptibility to nematode infection on phenotypic traits?

\subsection{Identification of less resistant animals in relation with age}

In sheep and cattle, the results from both experimental and natural infections have repeatedly established a clear difference in the immune response depending on age. In order to obtain a more sustainable control of these parasitic diseases, recent suggestions have been debated and proposed which take into consideration these differences by restricting treatments to the youngest animals of the flock in cattle [72] or sheep [46].
In goats, a lower divergence exists in the level of infection between young and adult goats which probably reflects the low ability of goats to develop an immune response against gastrointestinal nematodes [27,37]. Some observations obtained from natural infections indicate that adult goats are more infected than kids [58] but others find that the opposite is true [56]. However, in most systems of dairy goat production, goats less than one year old are conducted separately from the main flock, usually being kept indoors. Hence, the main epidemiological issue was to determine whether goats in first lactation and multiparous ones have or do not have differences in the level of egg excretion.

Recent examinations that address this last question have given contradictory results. A survey conducted for two successive years on an experimental flock showed significantly higher levels of infection in first lactation goats than in multiparous ones during the whole grazing season and particularly at the peak of parasitism [28] (Fig. 2a). This result confirms previous descriptions of higher egg excretion in one-year-old goats compared to adult ones [51]. These data underline the importance for goats of previous contacts with parasites in order to acquire a relative degree of immunity against worms, although the response appears longer to acquire and less intense than in sheep $[28,48,74]$. On the contrary, the conclusions derived from surveys conducted on farms to examine the potential difference between age, were more equivocal $[20,32,66]$. In such surveys on farms, several factors might have interfered with the influence of age on infection, such as (i) the breeding management of goats before the first lactation conditioning the occurrence or not of previous contacts with nematodes, (ii) possible separate grazing between first lactation and adult goats and (iii) the lighter weight of young goats which could explain less underdosing and a better 
a

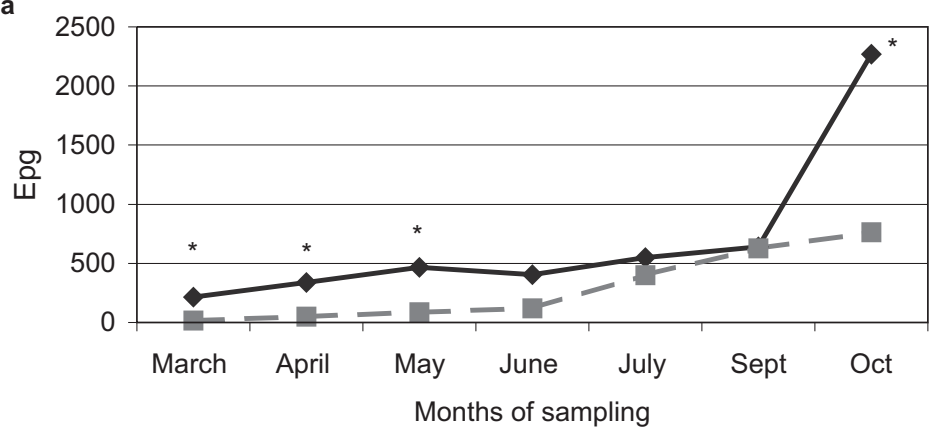

First Lactation $\rightarrow-$ Multiparous goats

b

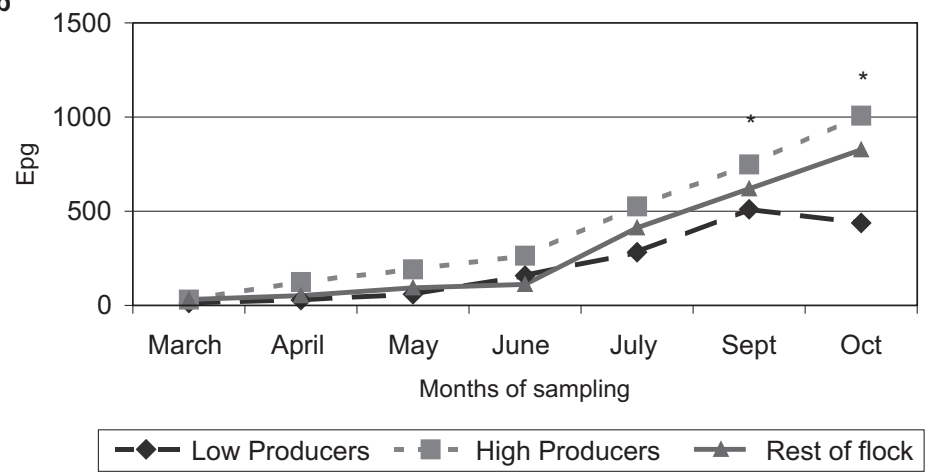

Figure 2. Identification of the less resistant goats within a naturally infected flock. Comparisons of nematode egg excretion between (a) multiparous and first lactating goats and (b) between the high producers (upper quartile), the low producers (lower quartile) and the rest of the multiparous goats. Goats are classified according to their level of milk production in the absence of parasitic challenge. All the goats were treated with an anthelmintic after October (* statistical difference between first lactation and multiparous goats or between high and low producers).

efficiency of anthelmintics in this category of hosts.

\subsection{Identification of less resistant/resilient animals related to the level of production}

Genetic selection and improvement of nutritional resources have allowed a general increase in the production levels of live- stock. However, it has also become apparent that high levels of production could be associated with negative side effects, including higher susceptibility to pathological processes, due to either excessive nutritional stress or genetic components $[14,57]$. In some instances, the differences in response to parasitism have been identified as some of the undesirable effects associated with high production. 
It has been suggested from both experimental studies and epidemiological surveys in dairy cattle that animals from high producing herds are more infected than others [44] and that, both on a herd and on an individual basis, high producing cows benefit more from anthelmintic treatments than low producing ones $[3,25,55]$.

In a similar way, several results in sheep have shown that the level of production is positively related to susceptibility to nematode infection. This was assessed on lines of sheep selected either for wool production or for meat production where faecal egg excretion or worm burdens were significantly higher as compared to values from non selected animals $[36,50,77]$. In addition, on a study measuring host resistance to internal parasites on lines of sheep selected for different traits of production, positive correlations calculated between lines were found between egg excretion and liveweight or wool growth [49]. In addition, a significant positive genetic correlation was also calculated between trichostrongyle egg output and fleece weight within selection lines [49]. In contrast, in a number of situations, significant negative genetic correlations were established between faecal egg counts and production traits as the growth rate in lambs [2, 5] or kids [48], or weight gain and fleece weight in Romney lambs [4]. In all cases, the phenotypic correlations were not significant.

In New Zealand, a negative genetic correlation has also been described between milk yield and faecal egg counts in Saanen dairy goats [51]. On the contrary, results from several other studies are concordant and strongly support the hypothesis that animals with the highest level of milk production are both less resistant and less resilient to gastrointestinal infection. The first studies on experimental infections with $H$. contortus and T. colubriformis showed that the high producers within a flock present a higher level of egg excretion than the low producers both after a single infection [26] or following repeated infections and challenge [9]. The results from surveys of specific flocks submitted to natural nematode challenges in oceanic and submediterranean climatic conditions confirm these experimental results. High producers within the flocks were found to be largely responsible for pasture contamination since their egg output exceeded the mean flock values by 10 to $120 \%$ depending on the season or environmental conditions [13, 28] (Fig. 2b). In addition, results from a larger scale survey conducted on 16 dairy goat farms from the three main regions of production indicate that goats with the highest level of milk production contribute more largely to flock egg excretion, both when referring to the mean annual excretion or to the peaks of parasitism [32].

Moreover, comparisons of pathophysiological parameters, related to the abomasal and intestinal lesions, and milk yield in these different studies indicate that high producing goats are less resilient to nematode infections than low producing ones. For example, the mean decreases in milk yield induced by mixed experimental infection during the first three months of lactation were evaluated to approximate $-18 \%$ in high producers but only to $-6 \%$ for the whole herd [26] (Fig. 3). As in dairy cattle, the responses in milk yield to anthelmintic drenches are also more prominent in the high producers than in low producing goats within the same flock $[8,28]$. Whether the origin of this higher receptivity and susceptibility to digestive parasitism in highly productive goats is due to a nutritional or a genetic component remains to be questioned, despite the recent results on interactions between the protein content of diet and nematode infection [17]. Whatever the origin, the overall results underline the major benefits which could be associated with the specific administration of anthelmintics to high producers, both to prevent pasture contamination and in terms of economic returns in milk yield following treatment. 


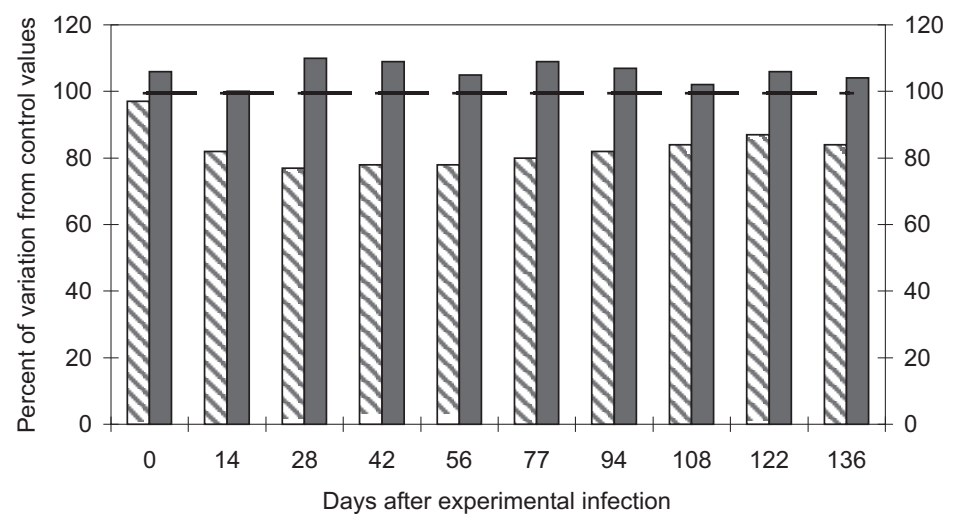

W\} \text { High Producers } \square \text { Low Producers } \square \text { control }

Figure 3. Lower resilience of high producing goats to experimental infection with Haemonchus contortus and Trichostrongylus colubriformis: comparisons of the relative effects (expressed as a percentage of production) on milk yield, by reference to non infected animals, with similar levels of production.

\section{EXPERIMENTAL ASSESSMENT OF SELECTIVE TREATMENT IN DAIRY GOATS}

The results from these experimental and epidemiological studies provide a rationale for the selective application of anthelmintics, during the grazing season, by targeting the less resistant and less resilient animals depending on age or level of milk production. Studies were then conducted to verify experimentally whether a selective treatment could be as efficient as a systematic one to control the gastrointestinal infections of goats and pasture contamination and to allow milk production. These points were first examined on an experimental flock and secondly, through a larger scale survey on farms in regions of goat production with contrasted climatic and epidemiological conditions. It is worth underlining that the selective applications of treatments were restricted to the time of goats being outdoors, which usually corresponds to lactation. During winter housing, a systematic treatment with a molecule from another anthelmintic family was applied.

\subsection{Studies on an experimental grazing flock}

For two successive years, a flock of 120 grazing, naturally infected Alpine dairy goats was divided into two groups: in the first one, all the animals were drenched; in the second group, only the high producing and first lactation goats received the treatments, and they represented respectively one half or two-thirds of the whole group, depending on the year. Both groups were conducted on separate pastures but with similar stocking rates. Teladorsagia circumcincta and Trichostrongylus colubriformis were the two dominant parasitic species on the site. The results from the comparisons were concordant for the two successive years. No differences in parasite infections were detected between the two groups whatever the mode of anthelmintic 
application, that is systematic or selective, as assessed by mean egg outputs, or pathophysiological parameters related to the abomasal or the intestinal species. Moreover, no differences in mean milk production were noticed between the two groups although 33 to $50 \%$ of the goats remained undrenched in the group receiving the selective treatment [33]. These first results hence suggest that (1) an effective control of infection with gastrointestinal nematodes might be achieved by relying on a selective treatment during grazing; (2) that this targeted application of anthelmintics has no detrimental effect on milk production; (3) that the proportion of goats left untreated (between one-third and one-half) does not modify these conclusions.

\subsection{Surveys of dairy goat farms in different areas of production}

To confirm the previous results from the experimental flock and to determine whether the nature and intensity of nematode challenges could interfere with the efficiency of the method, a survey was set up on 16 goat farms from three main areas of production in France (west, southwest and southeast). Due to the impossibility to divide farm flocks into two separate grazing groups, the survey was conducted for two successive years. Systematic treatments were given in year 1 . The following year, targeted treatments were applied on the flocks based on the same criteria of selection for the treatments (i.e. first lactation and high producing goats), with one-third of the flock remaining undrenched during the whole grazing season.

Again, the overall results did not indicate any major difference in the mean annual egg output in the 16 surveyed farms when switching from systematic to selective treatments. This similar efficiency associated with a reduced number of treated animals per flock was not compensated by any increase in the number of annual drenches since the mean annual number of treatments fell from 3.5 to 2.1. Lastly, the recorded annual milk production obtained from 10 farms did not show any major drop from year 1 to year 2 [34].

\subsection{Farm surveys for several years}

Results from the previous studies tend to confirm an absence of adverse consequences associated with targeted treatments. However, they cannot preclude any cumulative effect which can lead to negative consequences of parasitism, possibly postponed after several years of selective applications of anthelmintics during the grazing seasons. To examine this point, the farm survey was continued in one of the regions (southwest) for three years after the switch from systematic to selective treatments. Preliminary results have not shown any deterioration in the level of gastrointestinal infection, measured through egg output, nor any detrimental repercussions on milk production.

\section{CONCLUSIONS/PERSPECTIVES}

The ongoing work tends to indicate that selective treatment could represent one possible short term solution in dairy goat systems allowing to combine the control of nematode parasitism, maintenance of milk production and management of anthelmintic resistances. However, several basic and applied questions remain to be addressed in order to improve the method.

In particular, most of the data assuming that targeted treatments allow to dilute and delay anthelmintic resistances have been supported by theoretical considerations and mathematical models, but it seems essential to measure the real benefit associated with the selective treatments on the process of anthelmintic resistance through experimental studies. Similar studies should also provide 
data to determine more precisely which proportion of animals should be treated and which part can remain untreated in order to get the best balance between efficiency of control and management of nematode resistance. Lastly, since rapid identification of heavily infected animals is the cornerstone of the method, development of cheap, accurate methods of diagnosis, easily applicable on farms would represent a major issue in order to improve any application of selective treatment, by clear assessment of the most infected goats [21].

Although these points and many others remain to be explored, the results currently acquired provide data for possible implementation in the field of selective treatments during the grazing season. The method will have to be integrated and completed with other measures aiming at preventing the development of anthelmintic resistance, in particular the systematic treatment of the whole flock at housing with anthelmintics from other families. It is also important to stress that care should be taken when discriminating high vs. low producers based on data of milk production recorded at times when the nematode challenge is nil or low, since the more severe impact of parasitism on milk yield in high producing animals could induce mistakes in classification. Obviously, the method based on the phenotypic identification of goats depending on milk production is not suited for meat-producing goats which represent the main population in the world. For this type of animal, other options have to be considered such as the FAMACHA ${ }^{\circledR}$ system [68], since meat producing goats are mainly bred in tropical regions where $H$. contortus is the dominant species. The genetic selection for resistance is another option [48].

Lastly, when considering the difficulties to transmit simple messages to farmers and veterinarians, such as the necessity to double the recommended ovine dose of benzimidazoles in goats [29], it is clear that the implementation of selective treatments will require a huge effort for the dissemination of the results and for distributing information to the farmers.

\section{ACKNOWLEDGMENTS}

A large part of the works presented in this review received the financial support from the European Community (DG VI FAIR3 Project CT96-1485) and was part of a collaboration between Great-Britain, Greece and Spain.

\section{REFERENCES}

[1] Barnes E.H., Dobson R.J., Barger I.A., Worm control and anthelmintic resistance: adventures with a model, Parasitol. Today 11 (1995) 56-63.

[2] Bishop S.C., Bairden K., Mc Kellar Q.A., Park M., Stear M.J., Genetic parameters for faecal egg count following mixed, natural predominantly Ostertagia circumcincta infection in relationships with liveweight in young lambs. Anim. Sci. 63 (1996) 423-428.

[3] Bisset S.A., Marshall E., Morrison L., Economics of a dry cow anthelmintic drenching programme for dairy cows in New Zealand 1: overall response in 47 herds, Vet. Parasitol. 26 (1987) 107-118.

[4] Bisset S.A., Vlassoff A., Morris C.A., Southey B.R., Baker R.L., Parker A.G.H., Heritability of and genetic correlations among faecal egg counts and productivity traits in Romney sheep, N. Z. J. Agric. Res. 35 (1992) 51-58.

[5] Bouix J., Krupinski J., Rzepecki R., Nowosad B., Skrzyzala I., Robozynski M., FudalkwiczNiewczyk W., Skolska M., Malczewski A., Gruner L., Genetic resistance to gastrointestinal nematode parasites in Polish long wool sheep, Int. J. Parasitol. 28 (1998) 1797-1804.

[6] Cabaret J., Anthelmintic resistance in goats: from fictions to facts, 7 th International Conference on Goats, Tours, France, 15-18th May 2000, pp. 793-794.

[7] Cabaret J., Gasnier N., Farm history and breeding management influences on the intensity and specific diversity of nematode infections of dairy goats, Vet. Parasitol. 53 (1994) 219-232.

[8] Chartier C., Hoste H., Anthelmintic treatments against digestive-tract nematodes in grazing dairy goats with high or low levels of milk production, Vet. Res. 25 (1994) 450-457.

[9] Chartier C., Hoste H., Response to challenge infection with Haemonchus contortus and 
Trichostrongylus colubriformis in dairy goats: differences between high- and low-producers, Vet. Parasitol. 73 (1997) 267-276.

[10] Chartier C., Hoste H., La thérapeutique anthelminthique chez les caprins, Point Vét. 28 (1997) 125-132.

[11] Chartier C., Reche B., Gastrointestinal helminths and lungworms of French dairy goats: prevalence and geographical distribution in Poitou Charentes, Vet. Res. Comm. 16 (1992) 327-335.

[12] Chartier C., Pors I., Hubert J., Rocheteau D., Benoit C., Bernard N., Prevalence of anthelmintic resistance nematodes in sheep and goats in Western France, Small Rumin. Res. 29 (1998) 33-41.

[13] Chartier C., Etter E., Hoste H., Pors I., Mallereau M.P., Broqua C., Mallet S., Koch C., Masse A., Effects of the initial level of milk production and of the dietary protein intake on the course of natural nematode infection in dairy goats, Vet. Parasitol. 92 (2000) 1-13.

[14] Coop R.L., Kyriazakis I., Nutrition-parasite interaction, Vet. Parasitol. 84 (1999) 187-204.

[15] Dash KM., Newman R.J., Hall E., Recommendations to minimise selection for anthelmintic resistance in nematode control programmes, in: Anderson N., Waller P.J. (Eds.), Resistance in Nematodes to Anthelmintic Drugs, Australian Wool Corporation Technical Publication, Melbourne, 1985, pp. 161-169.

[16] Edwards J., Chapman H., Dunsmore J., Evaluation of the crack approach for the control of drench resistance in sheep worms, J. Agric. West. Aust. 30 (1989) 116-119.

[17] Etter E., Contrôle intégré des strongyloses gastro intestinales en élevage caprin laitier : l'amélioration de la réponse de l'hôte par l'alimentation, Thèse de Doctorat de l'Institut National d'Agronomie Paris Grignon, Septembre 2000.

[18] Etter E., Chartier C., Hoste H., Pors I., Bouquet W., Lefrileux Y., Borgida L.P., The influence of nutrition on the PeriParturient Rise in fecal egg counts in dairy goats: results from a two-year study, Rev. Méd. Vét. 150 (1999) 975-980.

[19] Etter E., Hoste H., Chartier C., Pors I., Koch C., Broqua C., Coutineau H., The effect of two levels of dietary protein on resistance and resilience of dairy goats experimentally infected with Trichostrongylus colubriformis: comparison between high and low producers, Vet. Res. 31 (2000) 247-258.

[20] Etter E., Chartier C., Hoste H., Pors I., Le Frileux Y., Broqua C., Vallade S., Goudeau C., Parasitisme par les nématodes du tube digestif et utilisation du pâturage : Épidémiologie de l'infestation dans les troupeaux caprins laitiers en France, Epidémiologie et Santé Animale 37 (2000) 75-86.
[21] Eysker M., Ploeger H.W., Value of present diagnostic methods for gastrointestinal nematode infections in ruminants, Parasitology 120 (2000) S109-S119.

[22] Gasnier N., Cabaret J., Chartier C., Reche B., Species diversity in gastrointestinal nematode communities of dairy goats: species area and species climate relationships, Vet. Res. 28 (1997) 55-64.

[23] Gomez H.H., Georgi J.R., Equine helminth infections: control by selective chemotherapy, Equine Vet. J. 23 (1991) 198-200.

[24] Grimshaw W.T.R., Hong C., Hunt K.R., Potential for misinterpretation of the faecal egg count reduction test for levamisole resistance in gastrointestinal nematodes of sheep, Vet. Parasitol. 62 (1996) 267-273.

[25] Gross S.J., Ryan W.G., Ploeger H.W., Anthelmintic treatment of dairy cows and its effect on milk production, Vet. Rec. 144 (1999) 581-587.

[26] Hoste H., Chartier C., Comparison of the effects on milk production of concurrent infection with Haemonchus contortus and Trichostrongylus colubriformis in high- and low-producing dairy goats, Am. J. Vet. Res. 54 (1993) 1886-1893.

[27] Hoste H., Chartier C., Résistance des chèvres aux strongyloses gastrointestinales : différences avec les moutons, Point Vét. 29 (1998) 69-74.

[28] Hoste H., Le Frileux Y., Pommaret A., Gruner L., Van Quackebeke E., Koch C., Importance du parasitisme par des strongles gastro-intestinaux chez les chèvres laitières dans le Sud Est de la France, Prod. Anim. (Paris) 12 (1999) 377-389.

[29] Hoste H., Chartier C., Etter E., Goudeau C., Soubirac F., LeFrileux Y., A questionnaire survey on the practices adopted to control gastrointestinal nematode parasitism in dairy goat farms in France, Vet. Res. Commun. 24 (2000) 459-469.

[30] Hoste H., Le Frileux Y., Pommaret A., Distribution and repeatability of fecal egg counts and blood parameters in dairy goats naturally infected with gastrointestinal nematodes, Res. Vet. Sci. 70 (2001) 57-60.

[31] Hoste H., Chartier C., Napoleone M., Picquart H., Pors I., Koch C., Suivi épidémiologique des infestations parasitaires du tube digestif dans 4 élevages caprins laitiers du sud est de la France: conséquences sur les courbes de production laitière, Rev. Méd. Vét. 152 (2001) 681-690.

[32] Hoste H., Le Frileux Y., Goudeau C., Chartier C., Broqua C., Bergeaud J.P., Distribution and repeatability of nematode faecal egg counts in dairy goats: results from a farm survey and implications for worm control, Res. Vet. Sci. 72 (2002) 211-215.

[33] Hoste H., Le Frileux Y., Pommaret A., Soubeyrat M., Ferrer M., Maîtrise du parasitisme par les strongles gastrointestinaux chez les caprins 
laitiers : essai d'application ciblée de traitements anthelminthiques, 7es Rencontres Recherches Ruminants, Paris, France, 6-7 December, 2001, pp. 91-94.

[34] Hoste H., LeFrileux Y., Chartier C., Goudeau C., Broqua C., Bergeaud J.P., Dorchies Ph., Efficacy of targeted application of anthelmintic to control trichostrongylosis in dairy goats, 18th WAAVP Meeting, Stresa, Italy, 26-30 August 2001.

[35] Hoste H., Chartier C., Etter E., Coop R.L., Kyriazakis I., Interaction nutrition-parasitisme: l'alimentation peut elle représenter une alternative aux traitements antiparasitaires? Bull. GTV, Hors série Spécial Agriculture Biologique, 2001, pp. 71-75.

[36] Howse S.W., Blair H.T., Garrick D.J., Pomroy W.E., A comparison of internal parasitism in fleeceweight-selected and control Romney sheep, Proc. N. Z. Soc. Anim. Prod. 52 (1992) 57-60.

[37] Huntley J.F., Patterson M., McKellar A., Jackson F., Stevenson L.M., Coop R.L., A comparison of the mast cell and eosinophil responses of sheep and goats to gastrointestinal nematode infections, Res. Vet. Sci. 58 (1995) 5-10.

[38] Jackson F., Anthelmintic resistance - the state of play, Br. Vet. J. 149 (1993) 123-138

[39] Jackson F., Options for the sustainable control of gastrointestinal nematode infections in goat production systems in Europe, 7th Int. Conf. on Goats, Tours, France, 15-21 May 2000, pp. 789792.

[40] Jackson F., Coop R.L., The development of anthelmintic resistance in sheep nematodes, Parasitology 120 (2000) S95-S107.

[41] Jackson F., Jackson E., Coop, R.L. Evidence of multiple anthelmitic resistance in a strain of Teladorsagia circumcincta isolated from goats in Scotland, Res. Vet. Sci. 53 (1992) 371-374.

[42] Kerboeuf D., Hubert J., Benzimidazole resistance in field strains of nematodes from goats in France, Vet. Rec. 116 (1985) 133

[43] Keyyu J.D., Kassuku A.A., The distribution of nematode egg counts in grazing goats and its implications for helminth control, 17th WAAVP Conference, Coopenhagen, Denmark, 15-19 August 1999.

[44] Kloosterman A., Ploeger H.W., Pieke E.J., Lam T.J.G.M., Verhoeff J., The value of bulk milk ELISA Ostertagia antibody titres as indicators of milk production response to anthelmintic treatment in the dry period, Vet. Parasitol. 64 (1996) 197-205.

[45] Krecek R.C., Guthrie A.J., Van Nieuwenhuizen L.C., Booth L.M., A comparison between the effects of conventional and selective antiparasitic treatments on nematode parasites of horses from two management schemes, J. S. Afr. Vet. Assoc. 65 (1994) 97-100
[46] Leathwick D.M., Vlassoff A., Barlow N.D., A model for nematodiasis in New Zealand lambs: the effect of drenching regime and grazing management on the development of anthelmintic resistance, Int. J. Parasitol. 25 (1995) 1479-1490.

[47] Maingi N., Bjorn H., Dangolla A., The relationship between faecal egg count reduction and the lethal dose $50 \%$ in the egg hatch assay and larval development assay, Vet. Parasitol. 77 (1998) 133-145.

[48] Mandonnet N., Aumont G., Fleury J., Arquet R. Varo H., Gruner L., Bouix J., Vu Tien Khang J., Assessment of genetic variability of resistance to gastrointestinal nematode parasites in Creole goats in the humid tropics, J. Anim. Sci. 79 (2001) 1706-1712.

[49] Mc Ewan J.C., Mason P., Baker R.L., Clarke J.N., Hickey S.M., Turner K., Effect of selection for productive traits on internal parasite resistance in sheep, Proc. N. Z. Soc. Anim. Prod. 52 (1992) 53-56.

[50] Morris C.A., Clarke J.N., Watson T.G., Wrigglesworth A.L., Dobbie J.L., Faecal egg count and food intake comparisons of Romney single trait selection and control lines, N. Z. J. Agric. Res. 39 (1996) 371-378.

[51] Morris C.A., Wheeler M., Hosking B.C., Watson T.G., Hurford A.P., Foote B.J., Foote J.F., Genetic parameters for milk yield and faecal egg count in Saanen does, N. Z. J. Agric. Res. 40 (1997) 523-528.

[52] Moskwa B., Charon K.M., Cabaj W., Rutkowski R., The mean, distribution and repeatability of in Polish Wrzosowka ewes following natural gastrointestinal nematode infection during two pasture seasons, Acta Parasitol. 43 (1998) 94-99.

[53] Patterson D.M., Jackson F., Huntley J.F., Stevenson L.M., Jones D.G., Jackson E., Russel A.J.F., Studies on caprine responsiveness to nematodiasis: segregation of male goats into responders and non responders, Int. J. Parasitol. 26 (1996) 187-194.

[54] Patterson D.M., Jackson F., Huntley J.F., Stevenson L.M., Jones D.G., Jackson E., Russel A.J.F., The response of breeding does to nematodiasis: segregation into responders and non-responders, Int. J. Parasitol. 26 (1996) 1295-1303.

[55] Ploeger H.W., Schoenmaker G.J.W., Kloosterman A., Borgsteede F.H.M., Effect of anthelmintic treatment of dairy cattle on milk production related to some parameters estimating nematode infection, Vet. Parasitol. 34 (1989) 239-253.

[56] Pomroy W.E., Lambert M.G., Betteridge K., Comparison of faecal strongylate egg counts of goats and sheep on the same pasture, N. Z. Vet. J. 34 (1986) 36-37.

[57] Rauw W.M., Kanis E., Noordhuizen-Stassen E.N., Grommers F.J., Undesirable side effects of selection for high production efficiency in farm 
animals: a review, Livest. Prod. Sci. 56 (1998) 15-33.

[58] Richard S., Cabaret J., Cabourg C., Genetic and environment factors associated with nematode infection of dairy goats in North Western France, Vet. Parasitol. 36 (1990) 237-243.

[59] Sangster N.C., Anthelmintic resistance: past, present and future, Int. J. Parasitol. 29 (1999) 115-124.

[60] Sangster N.C., Managing parasiticide resistance, Vet. Parasitol. 98 (2001) 89-109.

[61] Silvestre A., Chartier C., Sauve C., Cabaret J., Relationship between helminth species diversity, intensity of infection and breeding management in dairy goats, Vet. Parasitol. 94 (2000) 91-105.

[62] Silvestre A., Leignel V., Berrag B., Gasnier N., Humbert J.-F., Chartier C., Cabaret J., Sheep and goat nematode resistance to anthelmintics: pro and cons among breeding management factors, Vet. Res. 33 (2002) 465-480.

[63] Sreter T., Molnar V., Kassai T., The distribution of nematode egg counts and larval counts in grazing sheep and their implications for parasite control, Int. J. Parasitol. 24 (1994) 103-108.

[64] Stear M.J., Bairden K., Duncan J.L., Gettinby G., Mc Kellar Q.A., Murray M., Wallace D.S., The distribution of fecal nematode egg counts in Scottish Blackface lambs following natural, predominantly Ostertagia circumcincta infection, Parasitology 110 (1995) 573-581.

[65] Stear M.J., Bairden K., Bishop S.C., Gettinby G., Mc Kellar Q.A., Park M., Strain S., Wallace D.S., The processes influencing the distribution of parasitic nematodes among naturally infected lambs, Parasitology 117 (1998) 165-171.

[66] Vallade S., Hoste H., Broqua C., Lazare K., LeFrileux Y., Chartier C., Etter E., Relationships between nematode infection and farm characteristics in dairy goats in two French regions, Rev. Méd. Vét. 151 (2000) 1131-1138.

[67] Van Houtert M.F.J., Sykes A.R, Implications of nutrition for the ability to withstand gastrointestinal nematode infections, Int. J. Parasitol. 26 (1996) 1151-1168.
[68] Van Wyk J.A., Bath G.F., Practical methods of identifying individual animals for anthelmintic treatment within a group, Vet. Res. 33 (2002).

[69] Van Wyk J.A., Malan F.S., Bath G.F., Rampant anthelmintic resistance in sheep in South Africa: What are the options? in: Van Wyk J.A., Van Schalwyk P.C. (Eds.), Managing anthelmintic resistance in endoparasites, Workshop of the 16th WAAVP Conference, Sun City, South Africa, August 1997.

[70] Van Wyk J.A., Malan F.S., Randles J.L., How long before resistance makes it impossible to control some field strains of Haemonchus contortus in South Africa with any of the modern anthelmintics? Vet. Parasitol. 70 (1997) 111-122.

[71] Vatta A.F., Letty B.A., Van der Linde M.J., Van Wijk E.F., Hansen J.W., Krecek R.C., Testing for clinical anemia caused by Haemonchus spp. in goats farmed under ressource-poor conditions in South Africa using an eye colour chart developed for sheep, Vet. Parasitol. 99 (2001)1-14.

[72] Vercruysse J., Claerebout E., Treatment vs. non treatment of helminth infections in cattle: defining the threshold, Vet. Parasitol. 98 (2001) 195-214.

[73] Vercruysse J., Dorny P., Integrated control of nematode infections on cattle: a reality, a need? A future?, Int. J. Parasitol. 29 (1999) 165-175.

[74] Vlassof A., Bisset S.A., McMurtry L.W., Fecal egg counts in Angora goats following natural or experimental challenge with nematode parasites: within-flock variability and repeatabilities, Vet. Parasitol. 84 (1999) 113-123.

[75] Waller P.J., International approaches to the concept of integrated control of nematode parasites of livestock, Int. J. Parasitol. 29 (1999) 155-164.

[76] Waller P.J., Dash K.M., Barger I.A., Le Jambre L.F., Plant J., Anthelmintic resistance in nematode parasites of sheep-learning from the Australian experience, Vet. Rec. 136 (1995) 411-413.

[77] Williamson J.F., Blair H.T., Garrick W.E., Pomroy W.E., Douch P.G.C., The relationship between internal parasite burden, faecal egg count and mucosal mast cells in fleece weight selected and control sheep, Proc. N. Z. Soc. Anim. Prod. 54 (1994) 9-13. 